\title{
Toxicological Effects of Nanometer Titania on Chlorella
}

\author{
Zhiqin Chen \\ Jiangxi Key Laboratory of Surface Engineering \\ Jiangxi Science and Technology Normal University \\ Nanchang, China \\ e-mail: jxczqin@126.com \\ Zunming Guo \\ College of Materials and Mechanic \& Electrical \\ Jiangxi Science and Technology Normal University \\ Nanchang, China \\ e-mail: 18779886479@163.com
}

\author{
Hongying $\mathrm{Yu}$ \\ College of Materials and Mechanic \& Electrical \\ Jiangxi Science and Technology Normal University \\ Nanchang, China \\ e-mail: 424491369@qq.com \\ Shanshan Luo \\ School of Pharmacy \\ Jiangxi Science and Technology Normal University \\ Nanchang, China \\ e-mail: luoshanshan11@sohu.com
}

\begin{abstract}
The aim of this work was to investigate the effect of titania nanoparticles $\left(\mathrm{TiO}_{2} \mathrm{NPs}\right)$ on chlorella cultivated in modified Blue-Green medium (BG-11). The chlorella species were exposed for $96 \mathrm{~h}$ with a daily reading of the quantity of chlorella cultivated in modified BG-11 medium with different concentrations $(0,10,20,50,100 \mathrm{mg} / \mathrm{L})$ of anatase and rutile, respectively. Experimental results revealed the growth of chlorella was promoted in BG-11 medium with anatase during $48 \mathrm{~h}$ exposing, while inhibited at $96 \mathrm{~h}$. $\mathrm{TiO}_{2}$ NPs in rutile crystal structure had little impact on the growth of chlorella in the entire set of tests conducted. At low concentration $(<100 \mathrm{mg} / \mathrm{L})$, the influence of titanium ion concentration on the growth of chlorella was not obvious.
\end{abstract} rutile

Keywords-toxicological effects; chlorella; BG-11;anatase;

\section{INTRODUCTION}

Along with the widely application of nanomaterials in material science and nanotechnology, the risk of human exposure to nanometer materials is increasing, more and more importance is attached to the biological safety of them. The small particle sizes of nanomaterials make they have greater mobility and transmembrane abilities [1-2], which are more harmful. Many recent studies show that nanomaterials will induce the inflammation of target organ, prompt the oxidative stress reaction of body produces, and even enter the cell and the cell nucleus, and then exhibit the greater biological effect [3-4].

The algal cells are commonly used in experimental study of toxicity, because of the sensitivity to many poisons, a short growth period, which are easy to be isolated and can be observed directly on the cellular level of poisoning symptoms [5].

As an important industrial material, $\mathrm{TiO}_{2}$ nanoparticles $\left(\mathrm{TiO}_{2} \mathrm{NPs}\right)$ are widely used in numerous consumption products, such as sunscreens, cosmetics, paints and surface coatings [6-8], and in the environmental field: air soil and water decontamination processes [9-10]. Some of the toxicity studies were based on the evaluation of the potential toxicity of $\mathrm{TiO}_{2}$ NPs on human beings. It is found that $\mathrm{TiO}_{2}$ NPs and other nanoparticles can lead to lipid peroxidation, cell growth inhibition and photosynthesis inhibition in algae [11-13], and the degree of toxicity is depend on concentration and particle size, even in bulkier inert material [14].

This paper takes $\mathrm{TiO}_{2}$ NPs as the research object, and the aim is to investigate the biological toxicity of $\mathrm{TiO}_{2} \mathrm{NPs}$ on chlorella and provide data support for the biological toxicity evaluation of $\mathrm{TiO}_{2} \mathrm{NPs}$, by testing the influence of anatase and rutile on the growth of chlorella, respectively.

\section{EXPERIMENTS}

\subsection{Materials and Instrument}

Tetrabutyl titanate (CP), normal butyl alcohol (AR), ethanol (AR), Titanium tetrachloride (CP) and hydrochloric acid (AR) were purchased from commercial market. All reagents were used without further purification. Water was deionized and distilled before use. The BlueGreen medium (BG-11) was cultivated from our laboratory.

Nanometer titania (anatase and rutile) were prepared by the microwave digestion system (WX-4000 Shanghai Yiyao, China). The as-synthesis powders were characterized by X-ray diffractometer (D8 Advance, Bruker, Germany) and transmission electron microscopy (JEM-2010).

\subsection{Preparation of $\mathrm{TiO}_{2} \mathrm{NPs}$}

$\mathrm{TiO}_{2}$ NPs (anatase and rutile) were synthesized from our laboratory by microwave hydrothermal method, respectively. Single-phase and high purity nanocrystalline anatase was synthesized by hydrolysis of $\mathrm{Ti}\left(\mathrm{C}_{4} \mathrm{H}_{9} \mathrm{O}\right)_{4}$ at $120{ }^{\circ} \mathrm{C}$ for $1.5 \mathrm{~h}$ and then at $180{ }^{\circ} \mathrm{C}$ for $1 \mathrm{~h}$. Well crystallized and single-phase rutile was obtained by hydrolysis of $\mathrm{TiCl}_{4}$ first at $120^{\circ} \mathrm{C}$ for $1.5 \mathrm{~h}$ and then at $180^{\circ} \mathrm{C}$ for $1 \mathrm{~h}$. 


\subsection{Toxicity Test of $\mathrm{TiO}_{2} \mathrm{NPs}$ to Chlorella}

The $\mathrm{TiO}_{2}$ NPs suspensions were prepared in 5000 $\mathrm{mg} / \mathrm{L}$ stock solution with $\mathrm{BG}-11$ medium prior to the experiments. Inoculums of chlorella were grown in $250 \mathrm{ml}$ glass flasks containing $100 \mathrm{ml}$ of BG-11 medium at $(25+1){ }^{\circ} \mathrm{C}$. Five titanium ion concentrations $(0,10,20,50$, $100 \mathrm{mg} / \mathrm{L}$ ) of anatase and rutile were respectively added to the flasks from the stock solution of nanoparticle suspensions, which were treated with sonication after sterilization. The growth of chlorella was assessed by numbering algal cells in haemocytometer after different exposing times every 24 hours.

\section{RESULTS AND DISCUSSION}

\subsection{Characterization of the as-Synthesized $\mathrm{TiO}_{2} \mathrm{NPs}$}

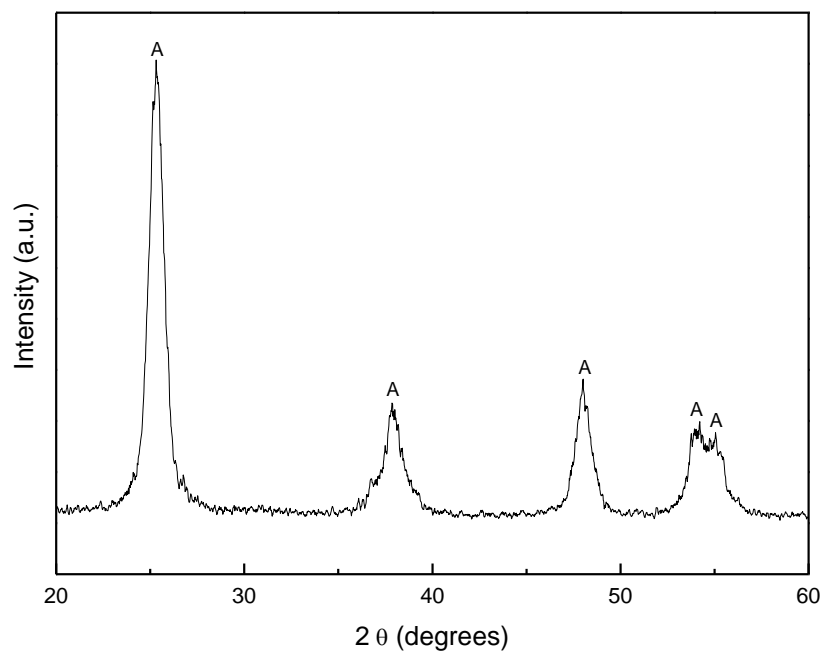

Figure 1. XRD spectrum of the as-synthesized $\mathrm{TiO}_{2}$ powder by hydrolysis of $\mathrm{Ti}_{(}\left(\mathrm{C}_{4} \mathrm{H}_{9} \mathrm{O}\right)_{4}$

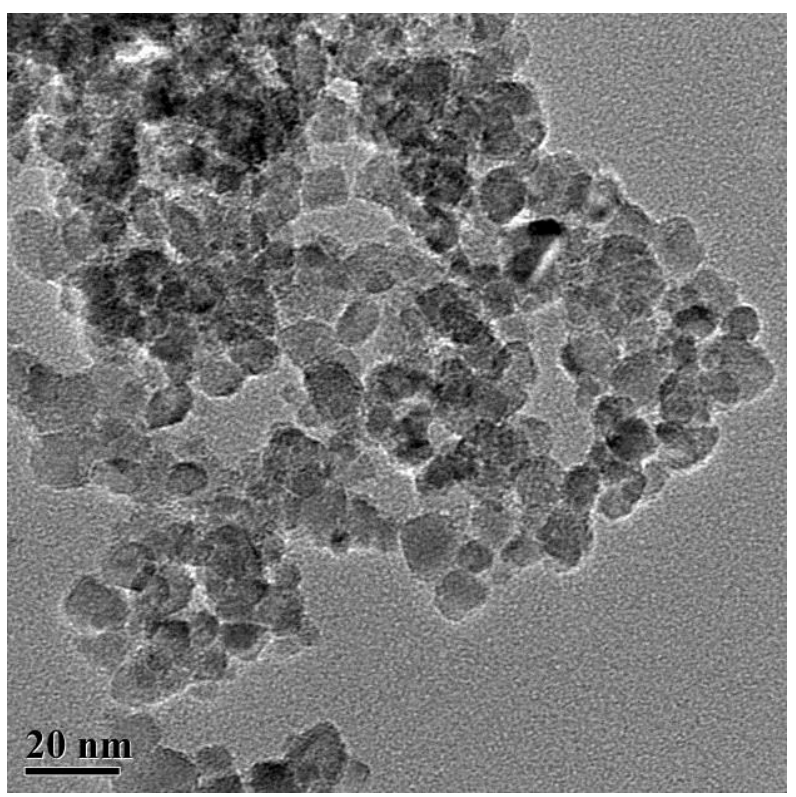

Figure 2. TEM photograph of the as-synthesized $\mathrm{TiO}_{2}$ powder by hydrolysis of $\mathrm{Ti}\left(\mathrm{C}_{4} \mathrm{H}_{9} \mathrm{O}\right)_{4}$.

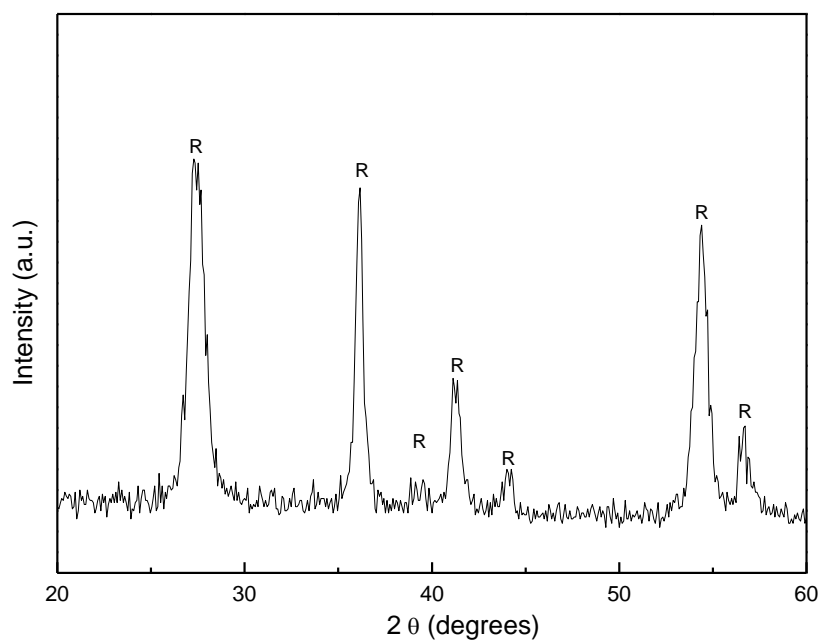

Figure 3. XRD spectrum of the as-synthesized $\mathrm{TiO}_{2}$ powder by hydrolysis of $\mathrm{TiCl}_{4}$

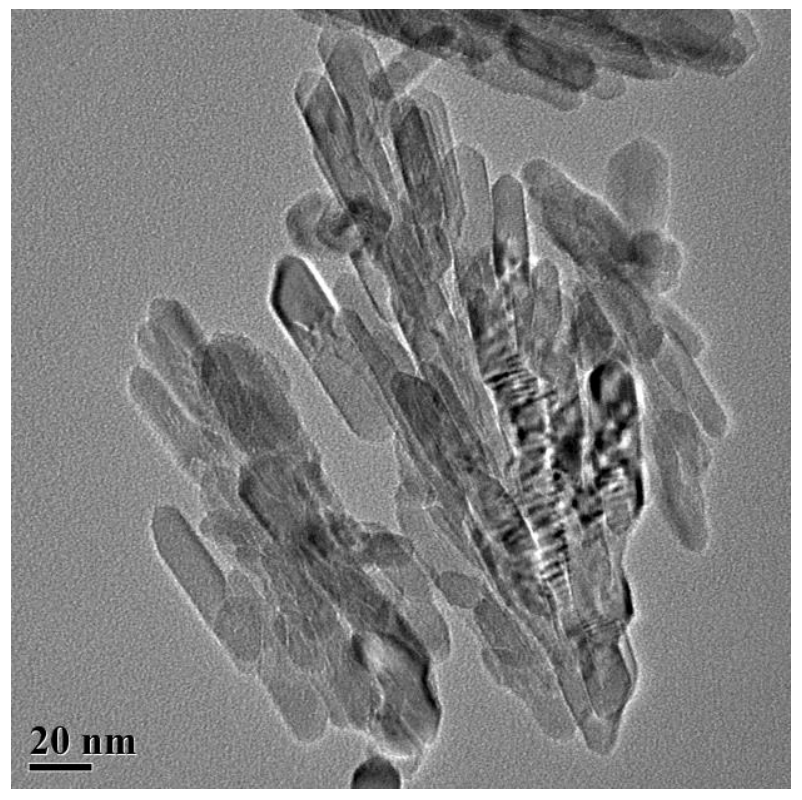

Figure 4. TEM photograph of the as-synthesized $\mathrm{TiO}_{2}$ powder by hydrolysis of $\mathrm{TiCl}_{4}$.

The XRD spectrum in Fig. 1 indicated that the assynthesized powder by hydrolysis of $\mathrm{Ti}\left(\mathrm{C}_{4} \mathrm{H}_{9} \mathrm{O}\right)_{4}$ was single-phase and high purity nanocrystalline anatase. Fig. 2 showed the TEM photographs of anatase exhibited granulous and uniformly dispersed, with the average crystallite size of $10 \mathrm{~nm}$.

Fig. 3 showed the result of XRD analysis of the assynthesized powder by hydrolysis of $\mathrm{TiCl}_{4}$. The XRD spectrum indicated the as-synthesized powder was well crystallized pure rutile. As shown in Fig. 4, the assynthesized rutlie was observed to be uniformly dispersed and exhibited shuttle-like morphology. The average diameter of rutile was about $10 \mathrm{~nm}$.

\subsection{Toxicological Effects of $\mathrm{TiO}_{2} \mathrm{NPs}$ on Chlorella}

The growth of chlorella was assessed by numbering algal cells in haemocytometer. The chlorella species were 
exposed for $96 \mathrm{~h}$ with a daily reading of the quantity of chlorella cultivated in modified BG-11 medium with different concentrations $(0,10,20,50,100 \mathrm{mg} / \mathrm{L})$ of anatase and rutile, respectively. The quantity of chlorella cultivated in BG-11 medium with different concentrations of anatase and rutile every 24 hours were listed in Table I and Table II, respectively.

TABLE I. QUANTITY OF CHLORELLA CULTIVATED IN BG-11 MEDIUM WITH DIFFERENT CONCENTRATIONS OF ANATASE

\begin{tabular}{cccccc}
\hline Time & $\begin{array}{c}\mathbf{1} \\
\mathbf{0 m g} / \mathbf{L} \\
\text { 个数 } \\
(\mathbf{1 0})\end{array}$ & $\begin{array}{c}\mathbf{2} \\
\mathbf{1 0 m g} / \mathbf{L} \\
\text { 个数 } \\
\left(\mathbf{1 0}^{\mathbf{4}}\right)\end{array}$ & $\begin{array}{c}\mathbf{3} \\
\mathbf{2 0 m g} / \mathbf{L} \\
\text { 个数 } \\
\left(\mathbf{1 0}^{\mathbf{4}}\right)\end{array}$ & $\begin{array}{c}\mathbf{4} \\
\mathbf{5 0 m g} / \mathbf{L} \\
\text { 个数 } \\
\left(\mathbf{1 0}^{\mathbf{4}}\right)\end{array}$ & $\begin{array}{c}\mathbf{5} \\
\mathbf{1 0 0 m g} / \mathbf{L} \\
\text { 个数 } \\
\left(\mathbf{1 0}^{\mathbf{4}}\right)\end{array}$ \\
\hline 0 & 278 & 278 & 278 & 278 & 278 \\
24 & 2745 & 2290 & 2910 & 2438 & 2195 \\
78 & 4470 & 9810 & 10995 & 7680 & 12345 \\
72 & 10560 & 9300 & 11970 & 9450 & 8400 \\
96 & 12000 & 11280 & 11355 & 12465 & 8715 \\
\hline
\end{tabular}

TABLE II. QUANTITY OF CHLORELLA CULTIVATED IN BG-11 MEDIUM WITH DIFFERENT CONCENTRATIONS OF RUTILE

\begin{tabular}{|c|c|c|c|c|c|}
\hline Time & $\begin{array}{c}1 \\
0 \mathrm{mg} / \mathrm{L} \\
\text { 个数 } \\
\left(10^{4}\right) \\
\end{array}$ & $\begin{array}{c}2 \\
10 \mathrm{mg} / \mathrm{L} \\
\text { 个数 } \\
\left(10^{4}\right) \\
\end{array}$ & $\begin{array}{c}3 \\
20 \mathrm{mg} / \mathrm{L} \\
\text { 个数 } \\
\left(10^{4}\right) \\
\end{array}$ & $\begin{array}{c}4 \\
50 \mathrm{mg} / \mathrm{L} \\
\text { 个数 } \\
\left(10^{4}\right) \\
\end{array}$ & $\begin{array}{c}5 \\
100 \mathrm{mg} / \mathrm{L} \\
\text { 个数 } \\
\left(10^{4}\right) \\
\end{array}$ \\
\hline 0 & 205 & 205 & 205 & 205 & 205 \\
\hline 24 & 1995 & 2433 & 2035 & 2353 & 2725 \\
\hline 48 & 11715 & 12120 & 12030 & 10848 & 14895 \\
\hline 72 & 9120 & 9120 & 10030 & 13650 & 9390 \\
\hline 96 & 9060 & 13590 & 8490 & 13320 & 11055 \\
\hline
\end{tabular}

The growth curve of chlorella cultivated in BG-11 medium with different concentrations $(0,10,20,50,100$ $\mathrm{mg} / \mathrm{L}$ ) of anatase and rutile were shown in Fig.5 and Fig.6, respectively.

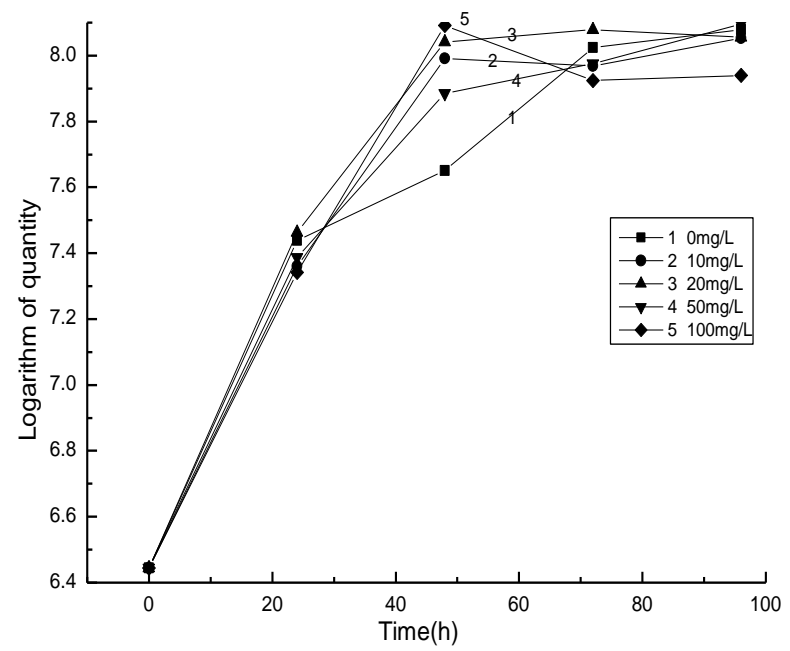

Figure 5. The growth of chlorella cultivated in BG-11 medium with different concentrations of anatase.
As shown in Fig.5, $\mathrm{TiO}_{2}$ NPs in anatase crystal structure accelerated the growth of chlorella during $48 \mathrm{~h}$ exposing. By stressing chlorella cell in favor of the activity of some enzymes, nanocrystalline anatase promoted the growth of chlorella. However, at $96 \mathrm{~h}$, the growth of chlorella cultivated in BG-11 medium with anatase was inhibited. The titanium ion concentration on the growth of chlorella is not obvious.

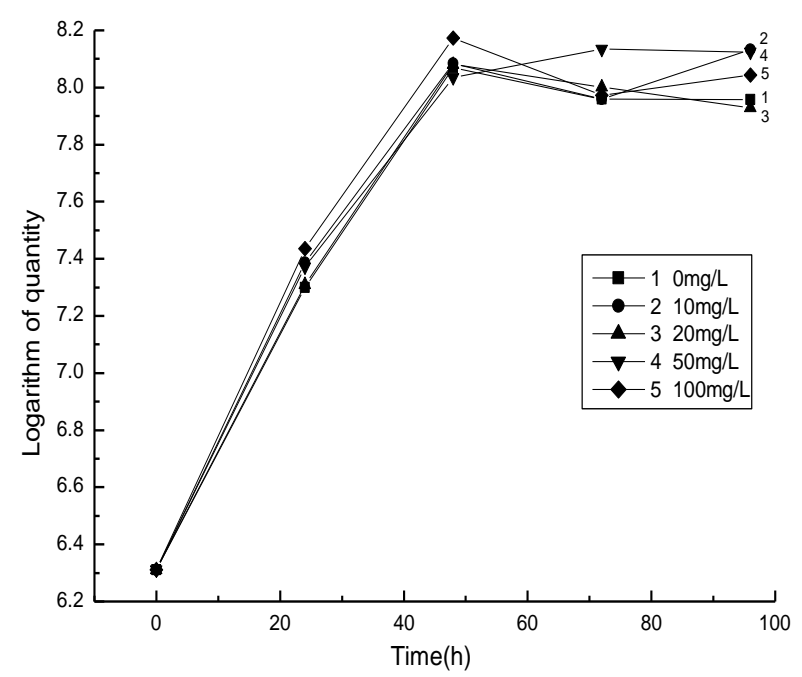

Figure 6. The growth of chlorella cultivated in BG-11 medium with different concentrations of rutile.

Fig.6 indicated that there were no significant differences among five growth curves, which showed that $\mathrm{TiO}_{2}$ NPs in rutile crystal structure have little impact on the growth of chlorella in the entire set of tests conducted. Because of its lipophilicity, the rutile crystalline structure of $\mathrm{TiO}_{2} \mathrm{NPs}$ formed larger aggregates in aqueous medium; then they had less effect on biological organisms, and thus a lower toxicity than the anatase crystalline form of $\mathrm{TiO}_{2}$.

\section{CONCLUSIONS}

At low concentration $(<100 \mathrm{mg} / \mathrm{L})$, the influence of titanium ion concentration on the growth of chlorella is not obvious. The growth of chlorella was promoted in BG-11 medium with anatase during $48 \mathrm{~h}$ exposing, while inhibited at $96 \mathrm{~h} . \mathrm{TiO}_{2} \mathrm{NPs}$ in rutile crystal structure have little impact on the growth of chlorella in the entire set of tests conducted.

\section{REFERENCES}

[1] Chithrani B. D., Ghazani A. A. and Chan W. C., "Determining the size and shape dependence of gold nanoparticle uptake into mammalian cells," Nanomaterial Letter, vol. 6, 2006, pp. 662-668.

[2] X.L. Jin, N. Zhang, X. Li and J. J. Yue, "Toxic effects of four nanoscale oxides on Chlorella vulgaris," Journal of Tianjin University of Technology, vol. 27, 2011, pp. 58-62.

[3] Nel, A., Xia, T., Madler, L. and Li, N., "Toxic potential of materials at the nanolevel," Science, vol. 311, 2006, pp. 622-627.

[4] L.Z. Chen, L.N. Zhou, Y.D. Liu, S.Q Deng, H. Wu and G.H. Wang, "Toxicological effects of nanometer titanium dioxide (nano- $\mathrm{TiO}_{2}$ ) on Chlamydomonas reinhardtii," Ecotoxicology and Environmental Safety, vol. 84, 2012, pp. 155-162.

[5] Kobraei M. E. and White D. S., "Effects of 2, 4 dichlorohenoxyacctic acid on Kentucky aglae: simultaneous 
laboratoryand field toxicity testings," Archives Environmental Contamination Toxicolology, vol. 31, 1996, pp. 571-580.

[6] Fisher, J. and Egerton, T., "Titanium Compounds, Inorganic. In: John Wiley \& Sons (Eds.), Kirk-Othmer Encyclopedia of Chemical Technology," New York, 2001.

[7] Kaida T., Kobayashi K., Adachi M. and Suzuki, F., "Optical characteristics of titanium oxide interference film and the film laminated with oxides and their applications for cosmetics," J. Cosmet. Sci. , vol. 55, 2004, pp. 219-220.

[8] Laura Clément, Charlotte Hurel, Nicolas Marmier, "Toxicity of $\mathrm{TiO}_{2}$ nanoparticles to cladocerans, algae, rotifers and plants-Effects of size and crystalline structure," Chemosphere, vol. 90, 2013, pp. 1083-1090.

[9] Esterkin, C.R., Negro, A.C., Alfano, O.M. and Cassano, A.E., “Air pollution remediation in a fixed bed photocatalytic reactor coated with $\mathrm{TiO}_{2}$," AIChE. J., vol. 51, 2005, pp. 2298-2310.

[10] Choi H., Stathatos E. and Dionysiou D.D., "Sol-gel preparation of mesoporous photocatalytic $\mathrm{TiO}_{2}$ films and $\mathrm{TiO}_{2} / \mathrm{Al}_{2} \mathrm{O}_{3}$ composite membranes for environmental applications Appl," Catal. B- Environ., vol. 63, 2006, pp. 60-67.

[11] Wang J.X., Zhang X.Z., Chen Y.S., SommerfeldM. and Hu Q., "Toxicity assessment of manufactured nanomaterials using the unicellular green alga Chlamydomonas reinhardtii," Chemosphere, vol. 73, 2008, pp. 1121-1128.

[12] Warheit D.B., Hoke R.A., Finlay C., Donner E.M., Reed K.L. and Sayes, C.M., "Development of a base set of toxicity tests using ultrafine $\mathrm{TiO}_{2}$ particles as a component of nanoparticle risk management," Toxicol. Lett., vol. 171, 2007, pp. 99-110.

[13] Aruoja V., Dubourguie H., Kasemets K. and KahruA., "Toxicity of NPs of $\mathrm{CuO}, \mathrm{ZnO}$ and $\mathrm{TiO}_{2}$ to microalgae Pseudokirchneriella subcapitata," Sci.Total Environ. , vol. 407, 2009, pp. 1461-1468.

[14] Shvedova, A.A., Kagan, V.E. and Fadeel, B., "Close encounters of the small kind: adverse effects of man-made materials interfacing with the nano-cosmos of biological systems," Annu. Rev. Pharmacol Toxicol., vol. 50, 2010, pp. 63-88. 